which revolve hold it in the correct plane.

The scanning device on the Orco-Graphic Reader presents such difficulty in use that it would not be practical to read unperforated film on it except where only occasional shifting was involved. Newspapers, then, while they can be read at
I5 $\mathrm{x}$ require too much shifting, but at $13 \mathrm{x}$ they are not large enough for easy reading. Most library microfilm except newspaper is photographed at reductions less than $15 \mathrm{x}$ and even $13 \mathrm{x}$. This machine will project a bright sharp image of unperforated film at I $3 \mathrm{x}$ or perforated at $15 \mathrm{x}$.

\title{
New Cooperative Research Project
}

A

NNOUNCEMENT is made of a new cooperative research project to prepare annotated lists and guides for: (I) medieval and Renaissance Latin translations from ancient Greek; and (2) medieval and Renaissance Latin commentaries on ancient Greek and Latin authors.

The list of translations will survey Latin translations, produced from antiquity down to A.D. 1600 , of Greek authors who wrote before A.D. 6oo. It will contain such information as the names of translators with short biographical data; date, place, and circumstances under which individual translations were made; incipits and explicits; references to manuscripts and printed editions containing the translations; and to recent scholarly literature on individual translators. This list will therefore provide a guide to the literary and documentary evidence available for an evaluation of the survival, rediscovery, and reception in the Latin West of ancient Greek writings from antiquity through the Middle Ages and the Renaissance to A.D. 1600 .

The list of commentaries will include information similar to that for translations regarding Latin commentaries, made from ancient times through A.D. 1600 , on authors of Greek and Latin antiquity who wrote before A.D. 60o. It will, however, for the present at least, exclude commentaries on Aristotle; on medical, legal, and canonistic works; on the Bible; and on mediaeval Latin authors. The listing of commentaries, which represent a common but comparatively neglected branch of literature, will supplement information contained in catalogs of old libraries and should provide tangible proof for an appraisal of the use or lack of use made of ancient authors through the centuries before A.D. 1600 .

The completed lists of medieval and Renaissance Latin translations and commentaries should have a direct value for scholars in the fields of history, literature, philosophy, and science. They should serve to illustrate and illuminate an important chapter in the development of scholarship from antiquity through the centuries to A.D. I600.

The project has been approved by the Committee on Renaissance Studies of the American Council of Learned Societies; by the American Philological Association; and by the Medieval Academy of America.

The following scholars are members of the editorial board: R. J. Clements, Harvard; M. E. Cosenza, Brooklyn College; J. Hutton, Cornell University; P. Kibre, Hunter College; P. O. Kristeller, Columbia ; D. P. Lockwood, Haverford; M. R. P. McGuire, Catholic University of America; B. Marti, Bryn Mawr; R. V. Merrill, University of Chicago; E. M. Sanford, Sweet Briar; J. J. Savage, Fordham; J. R. Strayer, Princeton; A. Taylor, University of California, Berkeley; S. H. Thomson, University of Colorado; B. L. Ulman, University of North Carolina. Inquiries regarding the project may be directed to any editor in the above list. 